\title{
一般口演 6
}

\section{㐘周炎患者にみられる咬筋筋活動の特性に関する研究}

\author{
A study on the characteristics of masseter muscle activity in periodontitis patients \\ ○加藤聖也 ${ }^{1)}$, 川上滋央 ${ }^{1)}$, Acing Habibie Mude ${ }^{1,2)}$, 皆木省吾 ${ }^{1)}$ \\ S. Kato ${ }^{1)}$, S. Kawakami ${ }^{1)}$, Acing Habibie Mude ${ }^{1,2)}$, S. Minagi ${ }^{1)}$ \\ ${ }^{1)}$ 岡山大学大学院医歯薬学総合研究科咬合・有床義歯補綴学分野 \\ ${ }^{2)}$ Hasanuddin University, Faculty of Dentistry, Department of Prosthodontics \\ ${ }^{1)}$ Department of Occlusal and Oral Functional Rehabilitation, Okayama University Graduate School of Medicine and Dentistry \\ ${ }^{2)}$ Hasanuddin University, Faculty of Dentistry, Department of Prosthodontics
}

I. 目的

ブラキシズムは過大な咬合力を伴うため, 歯の動摇, 咬耗や歯周疾患等と関連があることが示唆されている. ブラキシズムと歯周疾患の関係についてこれまで様々な 研究が行われているが, 多くは睡眠時のみを対象として いる。また，睡眠時ブラキシズムを対象とした研究にお いては EMG を用いた記録が行われているが，その一方 で覚醒時ブラキシズムについては主にアンケートを用い た評価が行われている。アンケート調査によるブラキ シズム診断の特異性は低いことが示唆されており ${ }^{1)}$, 歯 周炎患者の咬筋筋活動の特性を調査するためには終日の EMG 記録が必要である.

本研究は, 歯周炎患者の咬筋筋活動を携带型 $\mathrm{EMG} に$ より終日記録し，健常者と比較検討することを目的とし た。

\section{II. 方 法}

被験者はメインテナンスを目的として岡山大学病院予 防歯科を受診した患者のうち, 本研究のスクリーニング に同意が得られた患者 49 名とした. 本研究は岡山大学 倫理委員会の承認（第2027号）を得て実施された.

歯周状態に関するスクリーニングを受けた 49 人の被 験者については Center for Disease Control/American Association of Periodontology の基準に従って歯周炎の 重症度分類を行った. 本研究では No/Mild periodontitis (NMP) 群と Moderat/Severe periodontitis (MSP) 群の
2 群に該当する者を解析対象とした. NMP 群の包含基 準は，i）歯周炎なしまたは軽度の歯周炎，ii）歯周炎に よる梠失歯がないこととした，MSP 群の包含基準は，i） 中等度または重度の歯周炎，ii）残存歯または可撤性部 分床義歯に関する主観的問題がないこととした。NMP 群は 16 名（男性 3 名, 女性 13 名, 平均年齢 $64.5 \pm 11.4$ 歳), MSP 群は 15 名（男性 6 名, 女性 9 名, 平均年齢 $66.7 \pm 6.5$ 歳）であった. 18 名はこれらの群に該当しな かった。

EMGの記録は検査開始日の午前 12 時までに開始し， 翌朝被験者が起床するまで行った。咬筋筋活動の記録は 過去の報告に従い2)，以下の手順に従って行った；

(1) ディスポーザブルの表面電極（Vitrode F-150，日 本光電) を薄い生体適合性テープを用いて左側咬筋 中腹部に貼付した。

(2) 発話時の EMG 活動を区別するため，音声トリガー (VOX) スイッチを喉頭左側の頸部皮膚に貼付した。

(3) EMG レコーダー装着後，標準化のために左側第一 大臼歯部における $5 \mathrm{~N}$ 標準化噛みしめと最大自発噛 みしめを記録した。

(4)これらの記録の後, 被験者は翌朝起床時まで通常通 りの日常生活を送った。

記録された EMGデータをローパスフィル夕 (500 $\mathrm{Hz})$ とノッチフィルタ $(60 \mathrm{~Hz})$ でフィルタリングし たのち時定数 $10 \mathrm{msec}$ で RMS 化した. VOX 信号を伴 う $\mathrm{EMG}$ 信号は発話による活動とみなし分析から除外し た。咀嚼時の筋活動は EMG データと患者が記録した日 記を確認し，分析から除外した。 
EMG 解析閾值として $20 \% \mathrm{MVC} ， 5 \% \mathrm{MVC} ， 5 \mathrm{~N}$ 標準 化噛みしめ (5 N-VC) を用いた。咀嚼時と発話時を除 く全ての咬筋筋活動の累積持続時間を各閾值について 計算し， 1 時間当たりの持続時間として分析した。続 いて，代表的なブラキシズムエピソードである phasic, tonic, mixed について同様の解析閾値を用いて，1時間 当たりのエピソード持続時間として分析した。

$\mathrm{NMP}$ 群と MSP 群の咬筋筋活動時間の差について等 分散性の確認後に, Mann-Whitney U 検定を用いて検討 した。

\section{III. 結果及び考察}

食事と会話を除く平均咬筋筋活動時間は, 全ての解析 閾值において NMP 群に比べて MSP 群の方が長かった (図 1)。

続いて, Phasic, Tonic, Mixed 各エピソードの持続 時間をそれぞれの闇值ごとに比較した。覚醒時, 睡眠時 ともに全てのエピソードで NMP 群と比較して MSP 群 のエピソード持続時間の方が長かった。 (図 $2 \mathrm{a} \sim \mathrm{c}$ ).

本研究の結果から，歯周炎患者は健常者と比較して日 中および夜間の咬筋筋活動時間が長いことが示され，歯 周病の進行には咀嚼筋活動によって発生する力が関与し ている可能性があることが示唆された。

本研究は JSPS 科研費 $15 \mathrm{~K} 15706$ の助成を受けたもの である。

\section{N. 文献}

1) Manfredini D, Ahlberg J, Mura R, Lobbezoo F. Bruxism is unlikely to cause damage to the periodontium: findings from a systematic literature assessment. J Periodontol. 2015; 86 (4): 546-555.

2 ) Kawakami S, Kumazaki Y, Manda Y, Oki K, Minagi S. Specific diurnal EMG activity pattern observed in occlusal collapse patients: relationship between diurnal bruxism and tooth loss progression. PLoS One. 2014; 9(7): e101882.

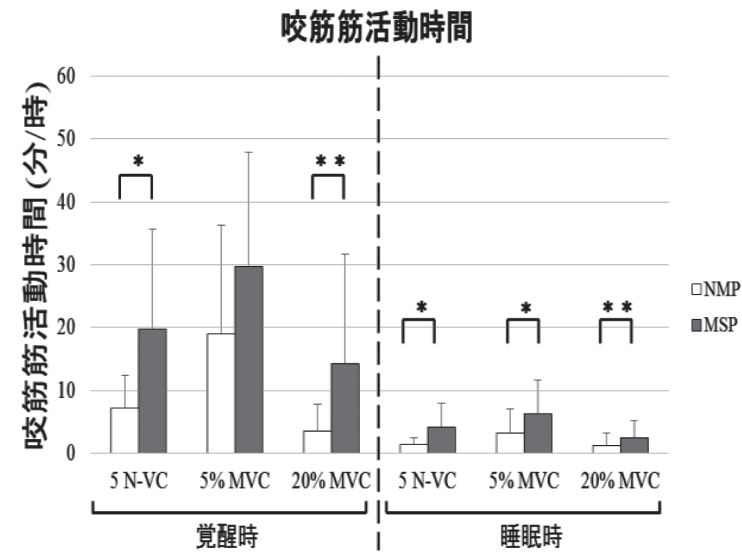

図 1 食事と会話を除く咬筋筋活動時間 $\left.{ }^{*}: p<0.05,{ }^{* *}: p<0.01\right)$
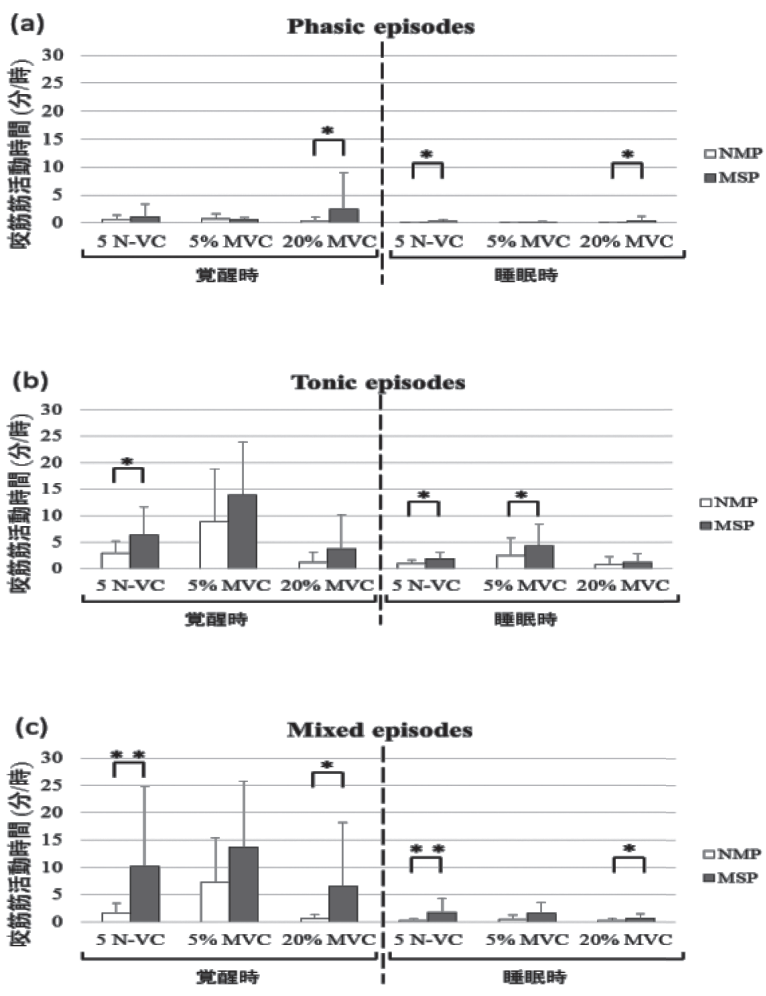

図 $2 \mathrm{a} \sim \mathrm{c}$ 各エピソードの持続時間 $\left(^{*}: p<0.05,{ }^{* *}: p<0.01\right)$ 